\title{
Government's Responsibility for Illegal Circulation of Imported Processed Food Products
}

\author{
Theresia Louize Pesulima ${ }^{1} \quad$ Ahmadi Miru ${ }^{2}$ Winner Sitorus ${ }^{3}$ Oky Deviany Burhamzah ${ }^{3}$ \\ 1.PhD Students at Postgraduate Programme, Faculty of Law, Hasanuddin University \\ 2.Professor on Legal Science, Faculty of Law, Hasanuddin University \\ 3.Associate Professor on Legal Science, Faculty of Law, Hasanuddin University
}

\begin{abstract}
The regulation of processed food products can be seen in Article 111 Paragraph (1), (2), and (6) the Law Number 36 of 2009 concerning Health. It also can be found in Article 37, 93, and 94 the Law Number 18 of 2012 concerning Food. This research is a normative legal research to apply statuta and the conceptual approaches. The results of the research that the government's responsibility in carrying out the control function has not been optimal yet. Some obstacles are found in the context of the illegal circulation of imported processed food products such as limited facilities and infrastructure, limited human resource,s and lack of coordination between one institution and other institutions.
\end{abstract}

Keywords: Responsibility of Government, Illegal Circulation, Processed Food Products

DOI: $10.7176 / \mathrm{JLPG} / 88-21$

Publication date: August $31^{\text {st }} 2019$

\section{Introduction}

Food is basic needs in human beings life including processed food. The processed food is food or drinks produced by a particular method. The need for food products within a country can be satisfied with the way the products of the in the country or imported from abroad. Since the enactment of the free market, goods and services from abroad circulate freely in the Indonesian market and as a consequence imported products will often be found in Indonesia. Such conditions on the one hand have benefits for consumers because consumer needs for the desired food products can be met and increasingly diverse, but on the other hand, the position of businesses and consumers become unbalanced regarding the truth of a food product information and customer responsiveness.

The Law Number 36 of 2009 concerning Health (hereinafter referred to the Health Law) Article 111 Paragraph (1) and Paragraph (2) stipulates that food and drink used for the community must be based on health standards and / or requirements and can only be circulated after obtaining marketing authorization in accordance with statutory provisions. Article 111 Paragraph (6) furthermore regulates that food and drink that do not meet the standard requirements, health requirements, and / or endanger health as referred to in Paragraph (1) are prohibited from being circulated, withdrawn from circulation, revoked marketing authorization and confiscated for destruction according to the Law. The Law Number 18 of 2012 concerning Food in Article 37 stipulates that food imports carried out to meet domestic consumption needs must meet the safety, quality, nutritional requirements, and do not conflict with the religion, beliefs and culture of the people. Furthermore, in Article 93 and Article 94 of the Law Number 18 of 2012 stipulates that everyone who imports food for trade must meet food safety and quality standards. Therefore, if there is a violation of the provisions referred to, administrative sanctions in the form of fines, temporary suspension of production and / or distribution activities, withdrawal of food from circulation by producers, compensation and or revocation of business licenses.

In an effort to monitor and control the circulation of food products that do not meet the circulation requirements, the government's responsibility in terms of supervision is needed. However, the phenomenon is happening that the government has not fully performed its maximum control because the processed food products are found on the in illegal market. This condition indirectly could be bad for consumers in terms of both health and safety of consumers.

Several cases of illegal circulation of imported processed food products occurring in Indonesia, for example, are the findings of the Food and Drug Monitoring Agency (hereinafter abbreviated as BPOM) to various kinds of products that do not comply with the circulation procedures as follows: (i) In 2015, BPOM found unqualified food products with estimation to more than USD 450 million. The findings were obtained from the supervision of food products in Indonesia ahead of Eid. The food products were stored in an importer warehouse in Angke, West Jakarta. ${ }^{1}$; (ii) In 2016, BPOM seized 4.5 million illegal food products. Unauthorized import food products were found in Medan, Pekanbaru, Jakarta, Surabaya, Pontianak, Samarinda, Denpasar, Makassar and Manado. The types of products included milk, snacks, canned drinks, alcoholic drinks, syrups, coffee, chocolate, herbs and canned foods. These products were illegally imported through smuggling sea lanes by utilizing official non-

\footnotetext{
${ }^{1}$ See Beware of Illegal Food Products, Kompas.com, Accessed January 20, 2019.
} 
port lanes from several countries such as Malaysia, Korea, Taiwan, Singapore, Thailand, Turkey, United States, Italy, Netherlands, Australia, France, Spain, and Chile. ${ }^{1}$

Until now, BPOM is increasingly active in conducting food supervision. Take an example before the Eid ulFitr in 2019, BPOM officers have inspected 712 food distribution facilities and the result of it that there were still $40 \%$ of facilities that were categorized as Not Fulfilling Provisions (TMK) for selling with qualification expired, damaged, and TIE. Total findings of TMK food from these facilities were 152,065 packages. They consisted of $74 \%$ of TIE food, $23 \%$ of expired food, and 3\% of food in a damaged condition. Of all TMK facilities inspected, $43 \%$ of the total TMK food findings came from the warehouse of TMK distributors / importers totalling 177 facilities. Based on the location of the findings, the findings of damaged food are mostly found in Jayapura, Padang, Bandung, Aceh, and Manokwari with types of butter products, canned fish, flavoured drinks, soy sauce, and sweetened condensed milk. The expired food findings were found in Manokwari, Jayapura, Samarinda, Ambon and Denpasar with types of instant noodle products, food additives, biscuits, powdered drinks, and snacks. While TIE food was found in Lampung, Palembang, Mataram, Batam and Kendari with types of tea, salt, snacks, biscuits, sugar and flour products. ${ }^{2}$

From these cases, it is clear that illegal circulation of food products continues to increase. Therefore, the focus of this paper is the role of government supervision in protecting consumers against the circulation of processed food products that do not meet circulation standards?

\section{Research Methods}

The type of this research was a normative legal research to using the statuta and the conceptual approaches. The statute approach was carried out by examining all laws and regulations relating to the legal issues being handled. The conceptual approach itself was carried out by moving from development of views and doctrines in the relevant legal science.

\section{Analysis And Discussion}

3.1 Regulation on the Circulation of Imported Processed Food Products

Under Article 91 Paragraph (1) the Law No. 18 of 2012 on Food, it has been determined that in terms of security surveillance, quality, and nutrition, any processed food that is made domestically or imported for trade in retail packaging, food businesses must have a marketing authorization. Regarding the implementation of the control function of the BPOM, it is based on the Regulation of the Head of POM No. HK.00.05.23.1455, dated March 24, 2008 Concerning Supervision of Processed Food Entry. Article 3 of the Regulation governes, as follows:

1) Processed foods that are imported into Indonesian territory must meet the provisions of the laws;

2) In addition to meeting the provisions referred to in paragraph (1), approval must be obtained from the Head of the agency;

3) Provisions as referred to in Paragraph (1) and Paragraph (2) also apply to the import of raw materials, food additives, auxiliary materials, food ingredients and other ingredients.

Based on statistics from the Food and Drug Supervisory Agency (BPOM), the products that received the most Circulars in Indonesia in early January 2019 were processed food products. The processed food products that get a distribution permit reaches $89.2 \%$ with as many as 280 processed food distribution permits. ${ }^{3}$ Based on the above provisions, the circulation of processed food can only be carried out after completing administrative and technical documents. Administrative Documents, consisting of:

1. Results of distribution audit facilities;

2. Certificate of proof of product has international standard quality issued by an authorized or accredited institution such as an ISO 22000 certificate, certificate of good manufacturing practice (GMP), or a risk management charter;

3. Letter of appointment from an overseas company to the importer or distributor;

4. Health certificate or certificate of free sale;

5. Specifically for alcoholic beverage importers, it must be accompanied by a Business License (SIUP), Import Identification Number (API) or Determination Letter as a Registered Importer (IT);

6. If the registration is done electronically, a Notary Deed of Company Establishment must be attached;

7. If the registration is done manually with the help of other people's services, it must attach a power of attorney to register processed food.

While the Technical Documents, consisting of:

1. Composition or list of ingredients used;

2. Production process;

3. Latest laboratory test results or food processing analysis certificates for the high and medium risk processed

\footnotetext{
${ }^{1}$ See BPOM Confiscates 4.5 Million Illegal Food Products, Solopos.com, Accessed January 20, 2019.

${ }^{2}$ See BPOM Tightens Illegal and Sub-standard Food Control, Majalahcsr.id, Accessed July 25, 2019.

${ }^{3}$ See BPOM Pocket Book 2019, p.1.
} 
food categories;

4. Information about the shelf life;

5. Information about production codes;

6. Label design;

7. Product photos that display all the information on the label clearly and legibly;

8. Translations of labels other than English from sworn translators.

Article 4 of the regulation furthermore stipulates that processed food imported into Indonesian territory must fulfill the following requirements:

a. Having been tested or examined and declared to have passed in terms of safety, quality and nutrition by the authorized agency in the country of origin;

b. Testing and or examination as referred to in letter a must be proven by analysis certification from an accredited laboratory;

c. Processed food as referred to in letter (a) can and or be re-examined in Indonesia in terms of safety, quality and or nutrition before being circulated.

Meanwhile Article 5 stipulates that:

1) Every processed food that is imported into Indonesian territory to be traded in retail packaging must have a registration approval letter from the Head of Agency;

2) Excluded, for:

a. having a shelf life of less than 7 (seven) days at room temperature and or;

b. being entered into Indonesian territory in small amounts for the purposes of applying for registration, research or self-consumption.

In addition to these rules as mentioned above, there is also the Government Regulation No. 28 of 2004 Concerning the Safety, Quality and Nutrition. Article 37 Paragraph (2) of the Regulation governs the authority BPOM to control the processed food will be entered into Indonesian territory, as follows :

a. Food has been tested, inspected and / or declared to have passed in terms of safety, quality and / or nutrition by the authorized agency in the country of origin;

b. Food meets the requirements referred to in Article 21 (regarding the quality assurance system)

c. Food is accompanied by documents of results of tests and / or examinations as referred to in letter a; and

d. Food is first tested and / or inspected in Indonesia in terms of safety, quality and / or nutrition before distribution.

In addition to licensing requirements, the imported processed food products that want to circulate in Indonesia must first be inspected and declared to have passed safety, quality and nutrition. This requirement is certainly a form of effort to protect consumers. For the imported processed food products that have met the conditions under licensing and pass the test, the product will be given Circulation Permit Number begins with the code "BPOM RI ML". the Circulation Permit is the approval of the results of the assessment of the safety, quality, and nutritional criteria of processed food for distribution in Indonesia. Acquisition of the circulation permit is done by registering processed food products to BPOM, either manually or electronically with various requirements and criteria for processed food conform the BPOM Decree No. 26 of 2018 on Licensing Services Sought Integrated Electronic Sector of Food and Drugs and Regulation BPOM No. 27 of 2017 concerning Processed Food Registration.

\subsection{The Measurement of Government Control Against Illegal Circulation of Imported Processed Food Products}

Supervision is very important for a developing country for the smooth running of an organization's activities. The supervision can be a function controller for management to ensure that the plans that have been set can be seamless. So that the organization can achieve its every goal.

According to Basu Private, ${ }^{1}$ supervision is a function that ensures that activities can produce the desired results. Meanwhile, according to Komaruddin, supervision is related to the comparison between the actual implementer of the plan, and the beginning for corrective measures against deviations and meaningful plans. Arifin Abdurachman ${ }^{2}$ states further that supervision is an activity / activity process to find out the results of implementation, mistakes, failures to be corrected later and prevent the recurrence of those mistakes, as well as prevent so that the implementation does not differ from the plan that has been set. There is essentially to say that supervisory activity is not intended to find fault, but more focused on controlling the overall order management functionality to be more effective and efficient for the achievement of objectives. However, the supervision will lose its meaning if the results obtained are various irregularities, violations, etc., but no action is taken. In other words, the supervision will function if the results or findings are followed up. ${ }^{3}$

\footnotetext{
${ }_{1}^{1}$ Amran Suadi, Judicial Body Control System in Indonesia, Rajawali Press, Jakarta, 2014, p. 15.

2 Arifin Badurachman, General Management Basics Framework, Balai Bulu Ichtiar, Jakarta, 2001, p. 99.

${ }^{3}$ Hadari Nawawi, Strict Supervision in the Environment of Government Apparatus, Erlangga, Jakarta, 1995 , p. 95.
} 
The concept of supervision actually shows that the supervision is part of the management function, where it is considered as a form of inspection or control from the upper party to the below party. In management science, supervision is placed as the last stage of the management function. From the managerial point of view, supervision implies observation of the implementation of all organizational unit activities which are examined to ensure that all work that is being carried out in accordance with the plan has been determined, and with supervision can minimize the emergence of obstacles, while obstacles that have occurred can be immediately identified which then corrective action can be taken. Meanwhile, in terms of administrative law, supervision is interpreted as a process of activities that compares what is carried out with what is desired, planned, or ordered. The results of this monitoring must be able to show the extent of compatibility and incompatibility and find the cause of the incompatibility that arises. In the context of building a management of public governance that is characterized by good governance. The supervision is an important aspect to maintain the functioning of government as it should. ${ }^{1}$

The supervision is basically directed entirely to avoid the possibility of diversion or deviation from the objectives to be achieved. The supervision is expected to help implemented policies that have been set effectively and efficiently. In fact, through supervision there is an activity that is closely related to the determination or evaluation of the extent to which the implementation of work has been carried out. Supervision can also detect the extent to which the leader's policies are carried out and the extent of irregularities that occur in the implementation of the work.

Guidance and supervision is a manifestation of the responsibility of the government in order to protect the public against the illegal circulation of imported processed food products. It is because without proper supervision, it is feared that consumers can be harmed in terms of security and safety in consuming them. Therefore, the regulation issued will be a guarantee that can provide protection for consumers and create a balance of position between business people and consumers. So that each party can go hand in hand without mutually defeating each other.

The forms of supervision carried out by the government are divided into 2 types, namely preventive and repressive supervision. The preventive supervision carried out on an activity before the activity is carried out. It means that it is able to prevent irregularities. The repressive supervision is carried out on an activity after the activity is carried out or in other words the actions taken by the government after a deviation has occurred.

Advances in technology in various fields have brought rapid and significant changes, especially in the food or food industry and the increasing level of demand has led to the emergence of food production or food on a large scale and diverse variations in the community. The development of an increasingly global world through international trade has crossed national borders and is carried out easily and cheaply provides the possibility of risks in the form of the circulation of food that is not safe for the community. Indeed, it poses a major threat to public health. The government in this case has the responsibility to prevent the production and distribution of food products that threaten public health. Guidance and supervision is a form of government responsibility in order to protect the public from illegal circulation, including in terms of overseeing the safety of imported food that enters Indonesia. Due to without proper supervision, it is feared that consumers will experience losses from food products consumed.

In carrying out control and supervision in the field of medicine and food, BPOM as a Non-Departmental Government Institution (LPND) has the duty of the government in the field of drug and food control in accordance with the applicable laws and regulations. Its authority is such as granting permits and controlling drug distribution and food. This is based on the interests of consumers. As an institution that has the authority to issue policies in the field of drug and food control (regulatory authority), the government also carries out supervisory functions. The government must also be able to develop its competence and credibility (competent authority) in drug and food control in Indonesia which is internationally recognized. ${ }^{2}$

BPOM legally has a strong position in making a policy in the field of medicine and food in the context of carrying out surveillance of drugs and food that circulates in the territory of Indonesia. Its position as a NonDepartmental Government Institution when viewed in terms of the formation of laws and regulations in Indonesia, then as an independent institution directly responsible to the President in terms of filing the formation of legislation as long as it involves in the field of medicine and food in order to take a policy that refers to the applicable laws and regulations. The role of BPOM in carrying out its functions when related to the legal rules regulated in the rules of the State Administrative Law is mutually supportive and interrelated, because as an organization, the Food and Drug Supervisory Agency (BPOM) conducts the formation of regulations that are stipulated (beschiking).

In an interview with the Section Head of Certification and Consumer Information Services POM Maluku province, Mathias Sandy Tokan Ola, on October 18, 2018 stated that the BPOM given tasks and special powers

\footnotetext{
${ }^{1}$ Ibid.

${ }^{2}$ See the Presidential Decree No. 103/2001 concerning Position, Duties, Functions, Authority, Organizational Structure and Work Procedures of Non-Departmental Government Institutions as amended several times, most recently by the Presidential Regulation No. 64/2005.
} 
on processed food products, both products within the country and abroad are in accordance with the terms and there are already test results in accordance with the parameters required in the framework of licensing, except for home industry food products (P-IRT) in the case that licensing is a duty and authority of the Health Service. However, with existing facilities, BPOM can help the Health Office to conduct testing to be tested and examined. According to him, in carrying out the control function, if it is found some illegally circulating medicinal and food products, then BPOM also conducts integrated supervision involving the Trade Office, the Directorate General of Customs and Police. Mathias Sandy Tokan Ola argued further that in general the control function is already executed but it is not optimal due to the limited Human Resources (HR) either in the amount or quantity or in terms of quantity or capability competences. So that the level of understanding they are different then the follow-up can be different. Other reason beside human resources is the available infrastructure is still limited and there is a lack of coordination from the respective institutions or agencies. ${ }^{1}$

In addition to the Food and Drug Supervisory Agency (BPOM), there are several government agencies that are also responsible for providing protection to consumers against the illegal circulation of imported processed food products in Indonesia, including

a) Directorate General of Customs and Excise

Customs responsibility in terms of supervision related to the validity of import documents (letter of approval of release of goods / SPPB). Directorate of Enforcement and Investigation (P2) Customs and Excise is tasked with providing technical support for supervision in the field of customs including supervision of traffic of goods entering the area Indonesian customs. The technical thing done by the Director General of Customs and Excise when checking imported goods usually is the inspection of importer documents. Currently, a valid and comprehensive Import Certificate (SKI) has been issued by the National Agency for Drug and Food Control (BPOM). However, for imported food products in packaging that are circulating in Ambon City, the completion of the document in the entry of goods there is no direct supervision from Ambon Customs because imported food goods in containers are coming from Jakarta and Surabaya ports. ${ }^{2}$

b) Council of Industry and Trade, Maluku Province

The supervision conducted by the Council of Industry and Trade, Maluku Province is associated with licensing regulations as importers and distributors and regulatory policies in the field of import. The monitoring mechanism is by conducting periodic checks in the field / where imported processed food products are traded. The inspection carried out by the Council of Industry and Trade, Maluku Province is only limited to checking the physical condition of imported processed food products on the market, such as checking the registration code contained on the product packaging. This is regulated in Article 4 of the Decree of the Minister of Industry and Trade of the Republic of Indonesia No. 634/MPP/KEP/9/2002 concerning Provisions and Procedures for Supervision of Circulated Goods and or Services Circulating in the Market, where supervision is carried out on quality standards, labelling, standard clauses, after sales services, how to sell and advertise of goods circulating in the market. For certain circumstances, the Council of Industry and Trade, Maluku Province can invoke a laboratory test.

\section{Conclusion}

It can be concluded that the responsibility of the government in carrying out the control function is not optimal. So that the illegal circulation of imported processed food products is still being discovered. This is caused by limited facilities and infrastructure, limited human resources and lack of coordination between one institution / agency and other institutions / agencies. It is expected that each institution / agency can evaluate the results of their performance for the sake of future supervision to be run optimally and sustainably. Thus, legal protection for consumers of imported processed food products can be realized.

\section{Bibliography}

Amran Suadi, Judicial Body Control System in Indonesia, Rajawali Press, Jakarta, 2014.

Arifin Badurachman, General Management Basics Framework, Balai Bulu Ichtiar, Jakarta, 2001. Hadari Nawawi, Strict Supervision in the Environment of Government Apparatus, Erlangga, Jakarta, 1995.

\footnotetext{
${ }^{1}$ See Results of an Interview with the Head of the Certification Section and Consumer Information Services of Maluku Province POM Center, Mathias Sandy Tokan Ola, on 18 October 2018.

${ }^{2}$ See Results of the Interview with Nursalim (Head of Customs and Excise Service Section and Technical Support of KPPBC TMP C Ambon) on October 19, 2018
} 